\title{
7
}

\section{Philippe Chatrier: The Fight to Control Professional Tennis}

\author{
Emmanuel Bayle
}

Philippe Chatrier played a central and charismatic role in developing and organising tennis between 1970 and 1990, in France and around the world. Here we look more closely at Chatrier's work, examining how this exemplary figure transformed the French Tennis Federation (FFT) by implementing his conceptions of sport federation management and the way sport should be conducted, especially with respect to the relationship between professional/elite sport and grassroots sport. In fact, the FFT under Chatrier's leadership pioneered an innovative vision of how major Olympic sport organisations should be run, as the management principles and methods he adopted provided a new "strategic model" for the world of Olympic organisations. Chatrier's work at the FFT also throws light onto the struggle between federations and commercial sponsors for control over the sport business.

E. Bayle $(\varangle)$

Institute of Sports Studies (ISSUL), University of Lausanne,

Lausanne, Switzerland

e-mail: Emmanuel.bayle@unil.ch 
Most of the data and analyses presented here were collated during research for a management sciences doctoral thesis called "Management and performance of non-profit organisations: the case of national sports federations". The six sport federations studied included the FFT, which was analysed via direct observations, documents ${ }^{1}$ and around 40 interviews, conducted between 1993 and 1998, with directors, senior managers and employees who had worked for the FFT during Chatrier's presidency. The objective was to investigate the management methods used during the 1980s and 1990s, and determine how these methods evolved. These data were supplemented by:

- Further interviews to discern more clearly Philippe Chatrier's personality and managerial role. These interviews were with P. Darmon (interviewed in 2006), a former French $\mathrm{n}^{\circ} 1$ tennis player and director of Roland Garros, who was close to Chatrier; G. de Kermadec (interviewed in 2006), a former French $n^{\circ} 3$ tennis player, national technical director and the FFT's technical manager under Chatrier; Marie-Christine Peltre (interviewed in 2013), assistant general secretary of the FFT during the Chatrier era; Patrick Proisy (interviewed in 2013 and 2017), a former professional tennis player, finalist at Roland Garros in 1972 and international vice-president of the IMG Group; and Jean Lovera, a friend of Chatrier, former tennis player, architect responsible for modernising Roland Garros, and former regional tennis league president (interviewed in 2017).

- Numerous press cuttings relating to Philippe Chatrier's career and presidency of the FFT, together with FFT internal documents (minutes of general meetings) made available by the Tennis Museum.

- An account of Chatrier's life and work produced by the FFT.

Following a brief review of Philippe Chatrier's life and career in sports management, the present chapter focuses on the two decades (1972-1992) when Chatrier was president of the FFT and the ITE.

${ }^{1}$ Combination of internal FFT documents (reports of general meetings and board meetings) and external documents (studies and surveys focusing on tennis and the FFT).
We begin by examining the management principles involved in what can be called the "Chatrier system" and then discuss Chatrier's work on the international stage, showing how his approach to management impacted the FFT, the wider tennis world, the Olympic movement and international sport in general.

\section{Philippe Chatrier's Career}

Born in 1928 to a middle class family, Philippe Chatrier joined his first sports club at the very young age of six (1934). His fascination with the exploits of the all-conquering "Musketeers", who led France to six straight Davis Cup wins between 1927 and 1932, inspired him to take up tennis, which he played at an elite level from 1947 to $1956\left(n^{\circ} 6\right.$ in the French rankings in 1951). At the same time, he followed a career as a journalist (1952), creating the magazine Tennis de France in 1953, "for the pleasure of being able to berate the Federation...".2

Chatrier rapidly moved into sports administration. During his time as president of Chantilly's prestigious International Club du Lys, from 1965 to 1968, he tried to introduce the principles and methods followed by British sport. "He dreamed of creating a great club, inspired by the English system, with school in the morning and sport in the afternoon. He began by building 40 tennis courts (including three grass courts) and a swimming pool, and he also introduced rugby. He recruited the best specialists in these fields. That was a constant thread through everything he did. When there was still a schism between amateur and professional sport, he organised competitions involving both pros and amateurs, putting together a tournament with prizes but no money". ${ }^{3}$

After playing a key role in the advent of Open tennis (breaking down the divide between professionals and amateurs), at the end of 1968 Chatrier was appointed vice-president of the FFT, made captain of 2Delessalle, J.-C.; Navarro, G.; Rebière, G.; Chami, L.; Profession Président, Les Editions du sport,
1992, p. 118.

${ }^{3}$ Source: interview with P. Darmon. 
France's Davis Cup team and put in charge of sport policy. His ascent to the top of the FFT was "almost due to chance", ${ }^{4}$ because the presidency, then held by Marcel Bernard, only became vacant due to a Youth and Sport Ministry rule limiting the tenure of sport federation executives to two successive terms.

In fact, when Chatrier was elected president of the FFT, at the beginning of 1973, he was much more familiar with the ins-and-outs of international tennis than with the workings of grass-roots tennis (how the leagues, départemental committees and clubs functioned). ${ }^{5}$ Unlike most of France's sport federation presidents, he had never been president of a regional league. Nevertheless, he went on to hold several key positions in international and national sports governance during the 1970s and 1980s, including seven successive terms as president of the International Tennis Federation (ITF), between 1977 and 1991. From 1979 to 1985 he was also vice-president of the Professional Tennis Council, which administered both the men's and women's circuits. As vice-president of France's National Olympic and Sporting Committee (CNOSF) from 1982 to 1993, Chatrier lobbied hard and successfully for the reintegration of tennis (1988) and other professional sports into the Olympic programme. Appointed to the International Olympic Committee (IOC) in $1990,{ }^{6}$ the gradual encroachment of Alzheimer's disease, first diagnosed at the end of the $1980 \mathrm{~s}$, forced him to step down in 1996. He passed away four years later, on 23 June 2000. The Philippe Chatrier Foundation, presided by his son, provides financial support to people suffering from the disease that took his life, thereby honouring the memory of one of the greatest administrators in the history of French and international sport.

The young Chatrier was deeply impressed by France's tennis "Musketeers", whose exploits continued to be a source of inspiration throughout his career. He was also fascinated by Wimbledon,

${ }^{4}$ Source: interview with P. Darmon.

${ }^{5}$ Source: interview with an unpaid manager.

${ }^{6}$ When Chatrier joined the IOC, President Samaranch appointed him chairman of the important Olympic Games Program Commission, a position he held from 1992 to 1994. the temple of tennis traditions, adopting it as his role model for developing Roland Garros. ${ }^{7}$ His presidency of the FFT was anchored in tennis's traditions and history and marked by the strength of his commitment to the sport. An aphorism coined by Antoine de SaintExupéry- "a position is nothing if it does not give rise to action" - which Chatrier often quoted during press interviews, neatly summarises the way he viewed his presidency of the FFT. The excellent sporting, organisational and financial results achieved by the FFT under Chatrier's leadership led to him being re-elected unanimously in both 1981 and 1985 .

Although he devoted all his energy to his national and international positions, he never received any financial compensation for his work. When he was elected president of the FFT, he even appointed an outside manager to run his magazine, Tennis de France, in order to avoid any conflicts of interest. Nevertheless, he was a life-long advocate of remunerating the presidents of large sport federations. In 1983, at the age of 55 , he said to the press: "It isn't for my sake that the CNOSF is studying the possibility of paying administrators and elected officials......I am too old; I have my independence... However, it must not become a sinecure. After all, it would not be good if the president who succeeds me is not fully committed and leaves all the work to his senior managers. The boss has to be fully abreast of all the issues"8; "I think you need a post of president of the ITF, someone who is at the helm seven days a week, 365 days a year, therefore remunerated, and someone who is elected. I would not put this measure through for myself. ? Partly due to Chatrier's efforts, his successors-Brian Tobin, at the ITF, and Christian Bimes, (during his final term, from 2004) ${ }^{10}$ and Jean Gachassin (from 2009) at the FFTreceived a salary for their work.

${ }^{7 a}$ For him, Wimbledon was the summit of tradition and excellence that Roland Garros had to try and attain. The exploits of the "Musketeers" were his reference; he was always paying homage to them" (source: interview with P. Darmon). "He had a cult for the Grand Slam tournaments. He thought they were the guardians of the game and that they were a barrier against "money is all" ... his fight to get tennis back in the Olympics was part of the same outlook" (source: interview with a former assistant secretary general of the FFT).

${ }^{8}$ Interview with P. Chatrier in Tennis Magazine, May 1983

'Interview in Le Figaro 10 November 1989.

${ }^{10}$ Authorised by Article 6 of the 2002 Finance Act and its Implementation Order of 20 January
2004 , but a ceiling was placed on remuneration, which could not be greater than three times the 2004, but a ceiling was placed on remuneration, which could not be greater than three times the
social security ceiling that is, a maximum salary of social security ceiling, that is, a maximum salary of approximately 8500 euros per month. 

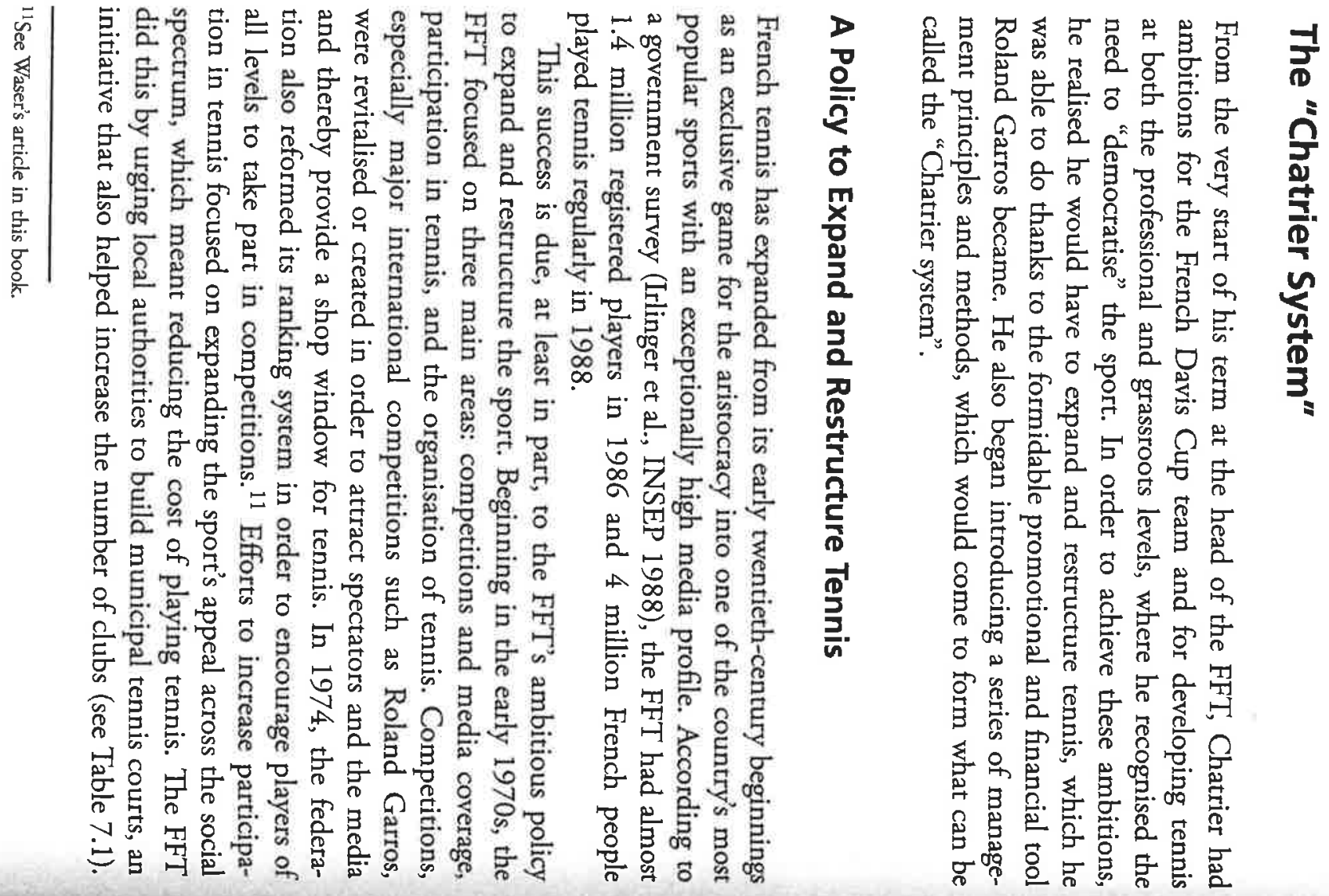

Table 7.1 Growth in clubs and players registered with the FFT between 1968 and 1996

\begin{tabular}{|c|c|c|c|c|c|c|c|}
\hline Year & 1968 & 1972 & 1978 & 1988 & 1990 & 1995 & 1996 \\
\hline Clubs (no. of courts) & $1330(4650)$ & 2151 & 4050 & 9755 & $10,206(35,000)$ & 9900 & 9704 \\
\hline Registered players & 134,000 & 224,442 & 545,254 & $1,364,902$ & $1,363,962$ & $1,093,398$ & $1,082,809$ \\
\hline $\begin{array}{l}\text { Mean growth in the number } \\
\text { of registered players belong- } \\
\text { ing to Olympic federations } \\
(1968-1978,1978-1988, \\
1988-1996)(\%)\end{array}$ & +47.7 & & $+60.1^{a}$ & & & $+2.5^{\mathrm{b}}$ & \\
\hline Growth in the FFT (\%) & +314 & & +146 & & & -20.7 & \\
\hline
\end{tabular}

aThis figure includes three newly Olympic sports: Baseball, tennis and table tennis (badminton is not included)

bThis figure does not take into account the addition of triathlon and taekwondo to the Olympic programme 
Another series of measures, including the opening of tennis schools (1971), the creation of tennis-study programmes (1972) and a fiveyear plan to restructure France's tennis "leagues" (late 1970s), was introduced in order to revamp the way tennis was organised. The timing of these initiatives, at the dawn of the Open (1969) and mass consumption and leisure eras, could not have been more fortuitous. ${ }^{12}$ What is more, increased media coverage of events such as Roland Garros ${ }^{13}$ was turning top tennis players into major international stars and the French government had agreed to provide financial support for the reorganisation of tennis. ${ }^{14}$ The result was a fifteen-year period of exponential growth in the FFT's membership, which increased from 224,442 in 1972 to $1,364,902$ in 1988 , a much faster rate than that achieved by any other French Olympic sport federation (Table 7.1).

A large part of this growth was due to tennis's increased attractiveness to the middle classes and its development, by 1988, into France's number one corporate sport. ${ }^{15}$ The game's rising popularity and wider appeal, achieved largely by harnessing the promotional and financial power of Roland Garros, led to the birth of a veritable tennis industry during the 1980 s. ${ }^{16}$

${ }^{12}$ See Terret T. (Ed.), Education physique, sport et Loisirs 1970-2000, AFRAPS, Paris (2003). ${ }^{13}$ The tournament was first shown on TV in 1973, with the first full TV coverage in 1976. 14“5000 tennis courts" initiative (1980-1985), "Indoor courts" initiative (1986-1990), provision of technical directors, etc. One interviewee suggested that Philippe Chatrier's friendship with Jacques Chaband-Delmas (French politician and talented tennis player) in the 1970 s contributed to the government's support for the FFT.

${ }^{15}$ Source: Reneaud, M. and Rollan, F., Tennis: pratiques et sociétés, Talence, Maison des Sciences de l'Homme d'Aquitaine (1995)

${ }^{16}$ The racket market grew at a rate of $15 \%$ per year between 1970 and 1980 , reaching a peak of 1.4 million rackets in 1981. In the mid 1980s, sales began to fall, with the marker evolving from new players to existing players changing their rackets. Source: M. Desbordes et al. (1999). The new players to existing players changing their rackets. Source: M. Desbordes et al. (1999). The
decline in racket sales continued throughout the 1980 s, reaching 640,000 rackets sold in 1988 (source: Sport Première magazine, July 1989, n¹87, p. 52).

\section{Roland Garros, an Essential Promotional and Financial Tool for the FFT}

From the very beginning of his presidency, Chatrier's aim was to use Roland Garros, which he saw as a lucrative, unifying and motivating event, ${ }^{17}$ to grow club membership and generate financial resources for the federation. Prior to the 1970s, Roland Garros had had modest resources and had not generated any profits for the FFT, ${ }^{18}$ but the tournament's newfound commercial success helped the FFT increase its budget from 859,000 francs in 1967 to 3.7 million francs in 1970, and to 11.9 million francs by $1975 .{ }^{19}$

When Philippe Chatrier took over at the head of the FFT, the facilities at Roland Garros were far below the level of those at the other Grand Slam tournaments. This is why, throughout the 1970s, the FFT reinvested most of the tournament's profits in extending and renovating the stadium. Without these investments it is doubtful whether the tournament would have become as profitable as it did during the late1980s and 1990s (Table 7.2), even though most of the growth in turnover between 1978 and 1993 was achieved by increasing receipts from television rights (multiplied by 264) and advertising revenues (multiplied by 24. Roland Garros Village, the tournament's public relations hub, was created in 1981). It was almost exclusively thanks to Roland Garros' profitability that the federation was able to increase its resources (approximately 300\% between 1988 and 1998) and improve its financial results.

Since the beginning of the 1980 s, the FFT has obtained between $80 \%$ and $85 \%$ of its income (depending on the year) from Roland Garros, whose continually growing profits have put the federation in a particularly stable and comfortable financial position. In fact, the structure of

Source: interview with Pierre Darmon.

${ }^{18}$ "Roland Garros existed thanks uniquely to ticket sales and a minor contribution from a single sponsor (Coca-Cola), who provided 5000 francs per year. Prices were very low, with half-price offers for registered players, in order to fill the stands. There was also a lot of fraud. Tickets were reimbursed in the asse of rain. The tournament was barely profitable at that time" (source: interview with P. Darmon). 
Table 7.2 Increase in earnings from Roland Garros between 1975 and 1998 (Source Interviews with Roland Garros managers and the federation's accounts)

\begin{tabular}{llllll}
\hline & 1975 & 1984 & 1988 & 1993 & 1998 \\
\hline $\begin{array}{c}\text { Turnover of Roland Garros } \\
\text { (turnover of Bercy from 1986) }\end{array}$ & $5.4^{\mathrm{a}}$ & $49^{\mathrm{b}}$ & $145(21)$ & $278(37)$ & $510(37)$ \\
$\begin{array}{c}\text { in millions of francs } \\
\text { Earnings (before depreciation } \\
\text { and provisions) in millions of } \\
\text { francs }\end{array}$ & 5 & 70 & 149 & 250 \\
\hline
\end{tabular}

a3,300,000 francs from ticket sales, $1,683,000$ francs from advertising revenue and 425,939 francs from TV rights

${ }^{2} 6.5$ million francs from ticket sales, 17.3 million francs from advertising revenue and 4.2 million francs from TV rights

the FFT's resources is very unusual for an Olympic federation, as it is one of the few that does not rely on direct subsidies from national government. Sports Ministry subsidies account for just 1\% of the FFT's budget, although the government continued to pay the salaries of a large number of technical directors throughout the 1980 s (68 technical directors in 1988).

This financial stability allowed Chatrier to build up the federation's head office, which had 150 salaried staff by the mid-1980s. In addition, since the early 1980 s a proportion of the FFT's revenues from Roland Garros has been channelled to the regional tennis leagues and départemental committees via a series of development contracts, which have helped clubs improve their facilities and increase their membership. Providing support to the regional leagues has also allowed the FFT to decentralise some former head-office functions to the leagues, initially by subsidising the salaries of the leagues' administrative and secretarial staff. ${ }^{20}$ Christian Bimes, who succeeded Chatrier in 1993, continued this policy. ${ }^{21}$ Subsidies for other managerial posts, introduced in the

${ }^{20}$ Source: General Secretary's Report, AGM, 1982.

${ }^{21}$ Subsidies to the leagues in the form of development contracts rose considerably between 1993 and 1998: 50 million francs in 1993, 63 million francs in 1994, 71 million francs in 1996 (including 48.4 million francs for the leagues and départemental committees and 22.6 million francs for the clubs), and 87 million francs in 1997 ( 57 million francs for the leagues and committees and 30.5 million francs for the clubs). Source: FFT's accounts. Subsidies to the clubs are channelled through the leagues (increasing the power and authority of the leagues). late $1980 \mathrm{~s}$ as a further measure to develop regional tennis, were used to recruit development advisors (1987), ${ }^{22}$ federal coaches for the leagues ${ }^{23}$ (1995) and départemental sports councillors (begun in 1996, widely implemented from 1998). ${ }^{24}$

Despite these development policies, the FFT saw a sharp and enduring fall in its membership in the late 1980 s and early 1990 s, with the number of registered players decreasing by 300,000 between 1986 and 1995. However, this phenomenon was not restricted to France. The United States, for example, had 13 million fewer regular tennis players in 1994 than in $1978 .{ }^{25}$ In addition to losing many teenage players, ${ }^{26}$ a trend that has hit most sport federations, tennis has been affected by competition from other sports and leisure activities, especially golf. Hence, while tennis lost 100,000 registered players between 1987 and 1992, golf gained 120,000 registered players (Reneaud and Rollan 1995). Reneaud and Rollan explain this change by referring to the work of sociologist Pierre Bourdieu: "the process of renewal in sports recruitment is based on mechanisms of distinction and difference in recreation. The more the middle classes take up tennis, the more the better-off classes will turn away from it" (p. 55).

Despite this slump in its membership, the FFT has achieved unparalleled growth compared with other sport federations, and this can be attributed, at least in part, to the managerial principles introduced during the Chatrier era. However, this growth has led to a proliferation of small clubs (which have received little help from the federation) to the detriment of France's great, historic clubs.

The post was created in 1987, with large-scale recruitment of full-time staff for almost all the leagues beginning in 1994 (FFT subsidy of 200,000 francs per year, per post).

${ }^{23}$ Training of top-class coaches within the leagues to assist the regional technical advisors. Subsidy provided by the FFT of 200,000 francs per year, per post.

${ }^{24}$ Originally entitled "departemental technical advisors", these posts were subsidised by the FFT to the rune of 150,000 francs per year.

${ }^{25}$ Source: Reneaud and Rollan (1995).

${ }^{26}$ The system for coaching young people used by tennis schools and at the top level is both very elitist and collectivist, which discourages many young players. 


\section{Innovative Management Principles and Methods}

At the beginning of the 1970 s, the FFT was run mostly by amateurs and "cut off from its roots" (Waser 1995). Philippe Chatrier's election as president saw a wind of change blow through the old-fashioned federation, as he introduced three highly innovative ideas about sport organisation management:

\section{Create a Collective and United Management Team}

Chatrier realised it would be easier to apply the federation's decisions regarding regional tennis if they were made in consultation with the presidents of all the regional leagues. In this, he was helped greatly by his general secretary, who worked tirelessly to ensure the leagues' support. ${ }^{27}$ In fact, the FFT's executive committee was firmly behind its president, especially during tennis's boom years (1975-1985), and was therefore able to ensure close political cooperation. ${ }^{28}$

\section{Delegate the Technical and Operational Management of Projects to Paid Staff}

Chatrier's management system was based on the idea that elected offcials and unpaid administrators should be responsible for defining policies, but professional managers should be recruited to implement these policies. Executives should be free to focus on their political role "so the unpaid administrators could hold onto their control over

${ }^{27}$ Charrier's decision to reduce the influence of the powerful Paris league by dividing it into individual leagues for each département in the Paris region (the other leagues cover an entire administrative region) was a "model of strategic politics" (source: interview with a former assistant general secretary)

${ }^{28}$ The FFT's board met more than 20 times in 1978 (source: 1978 report to the AGM), compared with 12 times a year in the late $1980 \mathrm{~s}$ and $1990 \mathrm{~s}$. These frequent meetings reflect the federation's administrators' need to coordinate the innovative changes being introduced at the end of the 1970 s. the development of tennis". ${ }^{29}$ Importantly, when choosing managers to carry out these tasks, Chatrier insisted on recruiting top-class people who believed in the tennis project (a sort of board he coordinated). Attracting the best managers not only meant paying higher salaries (comparable to those offered by large companies), ${ }^{30}$ it also meant delegating many managerial responsibilities and protecting managers' prerogatives. This Chatrier was able to do, thanks to his authority and charisma.

\section{Create a Federal Coaching System for Elite-Level Players}

Chatrier was well aware of how long it takes and how hard it is to train world-class athletes. Around ten years are needed to bring even the most talented athletes to the elite level, and tennis is no exception to this rule. Hence, his third innovation was a long-term project to create and finance a new coaching system for elite players. ${ }^{31}$ His first step, taken in 1969 , was to introduce a training scheme for managers and coaches. This was followed by a series of measures to open tennis schools (1971), set up "sport-study" classes (1972), and create of centres of excellence, first at the INSEP, and then at the National Training Centre ${ }^{32}$ (1987),

${ }^{20}$ Source; interview with an unpaid administrator on the executive committee duting the $1980 \mathrm{~s}$. 30These high salaries were due to Chatrier's desire to recruit talented professionals: "Recruiting competent staff was one of the president's clear wishes as of 1968 , so power remained with the elected be easier to control, he was clear-sighted enough to realise thated to recruit mediocre staff who would present or omni-competent. It was a revolutionary to realise that an unpaid manager could not be omnipresent or omni-competent. It was a revolutionary idea, when you think that the federation had consisted of a retired colonel and a few secretaries. He wanted to surround himself with talented people, whose salaries would reflect the commitment expected of them. He wanted to give them a real status so they would not be tempted by the siren-call of commercial companies" (source: interview with an unpaid FFT executive during the Chatrier era).

${ }^{\text {SI }}$ See A.-M. Waser's paper on this subject and Chatrier's fight during the 1960 s, most notably gallt $\mathrm{f}$ J. Borotra, to assist France's professional players with their training and careers.

"It was during the Chatrier era that the "marriage" between the "private" and "federal" training systems took shape. A journalist once asked whether the National Training Centre would just be a "super laboratory for the federation", Chatrier replied: "not at all. We will encourage just ment, comings and goings (between the two systems). This centre must be open to all types of initiative" (Interview in L'Equipe on 21 january 1986). 
which could provide large numbers of up-and-coming young players with sporting and financial assistance. In addition, in October 1976 Chatrier appointed a national technical director, J.-P. Loth, whose tasks included implementing a plan, unanimously approved by the executive committee, to "detect, teach, guide and train promising players aged between 12 and 20 ". ${ }^{33}$ By the late 1970s, the FFT's efforts had produced a highly effective system which quickly acquired an excellent reputation for the quality of its training and began producing a steady stream of top-class players. Most of France's champion tennis players are products of the "federal system", in contrast to other countries, where most elite players train at private facilities (such as the private academy set up by Nick Bollettieri), outside their federation's system. ${ }^{34}$

Despite the uncertainties involved in "manufacturing" a champion, which Chatrier frequently reiterated during interviews, ${ }^{35}$ the FFT's system has allowed France's elite tennis players (the "French school" of tennis) to consistently obtain excellent results at the highest level. Consequently, every year for the last 30 years France has had an average of 10-15 men and 10 women in the top 100 of their respective rankings (ATP for men, WTA for women). No other country since the advent of professionalism (1973), not even the United States, Sweden or Australia, has been able to equal this performance. However, even though France's national teams have achieved several successes in the Davis (men) and Federation (women) Cups during this period, few French tennis players have won Grand Slam tournaments. ${ }^{36}$ One reason for this may be that, unlike the club-and academy-based coaching

\footnotetext{
${ }^{33}$ Source: L'Express, 13-19 December 1976.
}

${ }^{34}$ Detractors of France's elite training system maintain that it is overly protective of young players, which is why they find it so difficult ("psychologically") to win the biggest tournaments, most which is why they find it
notably the Grand Slams.

${ }_{35 \text { "I }}$ believe that even the best system cannot produce champions, becoming a champion is a personal thing... ....you can't manufacture a champion. We guide athletes to the riverbank, but the land of champions is on the other side of the river. In the middle, there are crocodiles in the shape of oversized egos, the influx of money, media hype, the entourage, all that... If they get across, they are saved. They get their footing, they become champions".

${ }^{36}$ Source: Presentation by P. Bergues at the Sciences Po/FFT colloquium. Bergues was France's 8 th most successful player (percentage of matches won) in Grand Slam tournaments between 1968 and 2006. system in Spain, and the university and private-academy system in the United States, France's federal coaching system does not give young players the mental toughness needed to win individual tournaments.

\section{Chatrier's Work on the International Stage}

Internationally, Chatrier fought several battles, with varying degrees of success, in a business-minded sport whose international federation often struggled to impose its will and protect its interests. For example, he campaigned to keep the largest tournaments, especially the Grand Slams and Davis Cup, which he considered tennis's leading tournament, under federation control in order to protect and develop their sporting and symbolic value. He also lobbied successfully for tennis to be readmitted into the Olympic Games, attempted to regulate the commercialisation of tennis and tried to combat the intrusion of politics into sport.

\section{Keeping Tennis's Largest Tournaments Under Federation Control}

The dawn of the Open era, in 1968, brought ever-larger sums of money into tennis. In 1970 the Texan billionaire Lamar Hunt launched a professional winter circuit, called World Championship Tennis (WCT), which posed a serious threat to the so-called traditional tournaments. As a way of countering this alternative professional circuit, Jack Kramer, the father of professional tennis, convinced the ITF to set up a Grand Prix that would include the Grand Slam tournaments. Players won points based on their performances in these tournaments, with the number of points attributed depending on the tournament's standing. The top eight players in the resulting classification went on to play a "super final" at the end of the season. Hence, the Grand Prix and WCT circuits ran side-by-side in 1970 .

Now able to make a respectable living thanks to the large sums of money flowing into tennis, in 1972 professional players formed a "union", the Association of Tennis Professionals (ATP) to defend their 
interests against the ITF. Chatrier was in favour of players becoming organised (source: interview with former professional tennis player).

Events quickly led to a trial of strength between the ATP and the ITF. By 1973 relations between the two sides had become so strained that some players, notably Pilic, refused to play in the Davis Cup. After being suspended by his national federation, Pilic appealed to the ITF. The ATP flexed its muscles in support of Pilic by persuading 79 professional players to boycott Wimbledon, whose organisers did not want Pilic to take part in the tournament. The standoff between the ATP and ITF revealed a major shift in the balance of power. As Chatrier said: "That was the day the ATP realised how strong it was. From that moment on they were a force to be reckoned with. I had a vague feeling that players would sooner or later start playing a more active role in their affairs". 37

Chatrier was on the players' side, believing that the federation could no longer tell them what to do without letting them have their say. One of the results of the "Pilic" and "Wimbledon" affairs was to give players a voice through a new advisory body called the Professional Council, which was set up in 1973. The council, which organises the Grand Prix circuit and deals with issues within the professional game, consists of three representatives from each of the three main stakeholders, that is, players, major tournaments and the ITF. Philippe Chatrier was, from the very beginning, one of the ITF's three delegates.

However, an even greater danger was emerging in North America, with the imminent launch of World Team Tennis (WTT), "an inter-city tennis tournament that would fill the calendar from May to September without interruption". ${ }^{38}$ These exhibition tournaments were a direct threat to Roland Garros and traditional tennis. WTT, which was played between teams representing major American cities and to highly modified rules, quickly became popular. Consequently, on 14 February 1974 the ITF sent a circular to its member federations announcing

${ }^{37}$ Delessalle, J.-C.; Navarro, G.; Rebière, G.; Chami, L.; Profession Président, Les Editions du sport, 1992, p. 137.

${ }^{38}$ Haedens, Francis; "Le dossier de la crise du tennis", in Tennis de France, n'244, August 1973. p. 59. its decision to recognise the WTT competition, which "will be held between 6 May and 25 August, except during two weeks to allow players to prepare for and compete in the Wimbledon tournament". 39

Chatrier, as president of the FFT, was the first person to react, adamantly proclaiming "We are the guardians of a legacy that we must not abandon to sport's pimps". ${ }^{40}$ He launched his counter-attack on 15 February, clearly setting out his intentions:

We do not accept either of the two proposed solutions. Any player who signs a contract with WTT will be banned from playing at RolandGarros and in Davis Cup and Federation Cup matches. We are also considering refusing to play any Davis Cup team that includes players who took part in WTT. I invite the other federations to adopt the same position. ${ }^{41}$

Several other national federations joined with Chatrier and the FFT in their opposition to the ITF.

The situation came to a head at the 1974 edition of Roland Garros, when the FFT followed up its president's threat and banned four top players, John Newcombe, Tom Okker and Jim Connors, who was not yet a member of the ATP, and Evonne Goolagong. Connors and Goolagong tried to overturn the ban through the courts, but their case was thrown out and they were unable to play. Consequently, they could not attempt that year's Grand Slam (they had already won the Australian Open and Connors went on to win Wimbledon and the US Open), which, for the first time, came with a prize of $\$ 150,000$. Connors again sued the FFT, this time asking for damages of two million French francs. He finally abandoned his suit in the spring of 1975, but he continued to boycott Roland Garros until 1979 and he never managed to complete a Grand Slam.

A few months later, in the light of the ITF's decisions to recognise WTT and reject the idea of creating a mixed council consisting of four

39Haedens, Paul; "L'héritage du centenaire", in Tennis de France, n²52, April 1974, p. 12. "Quidet, Christian; La fabuleuse histoire du tennis, Nathan, 1984, p. 378.

"libid. 
members of the ITF and four members of the ATP, Chatrier, in the name of the FFT, declared: "Last weekend was the most tragic weekend in the history of tennis". ${ }^{42}$ However, the FFT's president would not give into the international status quo. Roland Garros was not the only tournament under threat; the Davis Cup was also in danger due to a lack of interest from players and the fall out from international politics.

\section{Defending the Davis Cup and Winning the ITF}

Although the Open era had allowed the Grand Slam tournaments to regain their former glory, the Davis Cup remained in the doldrums, partly because it remained an entirely amateur competition and therefore unable to benefit from the glamour of tennis's star players. Even when professionals were allowed to take part, few would give up the lucrative earnings of the Grand Prix and W'TT circuits for the "simple" honour of representing their country. The absence of tennis's leading nations, Australia, the United States, Great Britain and France, added to the competition's lacklustre image and led to some surprise results, as in 1974, when South Africa and India qualified for the final. ${ }^{43}$

However, the greatest threat to the Davis Cup was world politics, as international tennis matches became battlegrounds for nationalistic and ideological propaganda. 1976 was a turning point as, tired of seeing the Davis Cup "tarnished by countries dropping out for political reasons", ${ }^{44}$ the United States, which had created the competition, withdrew from the Assembly of Davis Cup Nations. The English and French federations also announced they would withdraw from the event in 1977 and were contemplating creating an identical but apolitical competition in its stead. Finally, all three countries decided to suspend their decisions for a year. Meanwhile, further incidents deepened the

42"Philippe Chatrier: 'La fédération internationale mène le tennis traditionnel à la catastrophe" in La Dépéche, 5 November 1973.

${ }^{43}$ The cup was awarded to South Africa, when India refused to play them in protest over Apartheid.

${ }^{44} \mathrm{Haedens}$, Paul; "Le sens caché du Challenge round", in Tennis de France, n²83, November 1976. crisis surrounding the Davis Cup, which was in danger of falling apart. In August 1976 the USSR, Czechoslovakia, Hungary and the Philippines withdrew from the Federation Cup (women's equivalent of the Davis Cup) due to the presence of South Africa and Rhodesia. Furthermore, the Soviet Union refused to play their semi-final against Pinochet's Chile in protest at "the blood bath and human rights violations being inflicted on Chile". ${ }^{45}$ In the end, given the lack of support from other countries and worried about "killing off the event", the United States, Great Britain and France went back on their decision to boycott the 1977 Davis Cup.

On 6 and 7 November 1976 the ITF and Davis Cup boards met in Paris to discuss the situation. Chatrier, who had seats on both boards, took part in the discussions. This time, Czechoslovakia, Hungary and the Philippines were excluded from the 1977 Federation Cup, and the USSR was excluded from that year's Federation and Davis Cups. This was the first time a national team had been excluded from the competition. These countries often claimed they were wronged by the ITF, as they felt they were just following United Nations policy.

Hence, at a time when tennis was growing in popularity around the world and gradually entering the age of television and commercialisation, the ITF was being battered by the assaults of entrepreneurs and the players' desire for independence and higher rewards. Simultaneously, the Davis Cup was foundering in a sea of politics and indifference. For example, in 1976 French players, some of whom were also members of the FFT's executive committee, refused to accept Chatrier's unilateral, last-minute decision to play in Portugal during the "carnation revolution". Chatrier responded by suspending two members of the French team for two matches.

During an interview with Tennis Magazine in June 1977, Chatrier was asked if he would stand for election as president of the ITF. He replied he would do so only if he were certain he would have the means to take action. At the time, he felt that the ITF had had its hands tied by the influx of money into the sport and America's antitrust laws,

"Côté court", in Tennis Magazine, December 1976, n9, p. 11. 
which prevented the ITF putting into some sort of order all the offcial and unofficial tournaments that then existed. The ITF also had its hands tied with respect to politics, with almost fatal consequences for the Davis Cup. Nevertheless, in July 1977 Chatrier stood for election as ITF president, against America's Sam Malles, and won $70 \%$ of the votes. After his victory he said he wanted "to give the federation a new image and greater influence over professional tennis". ${ }^{46} \mathrm{He}$ was re-elected in 1979, which made him the first ITF president to serve two consecutive terms, and went on to be re-elected unanimously at each of the next five elections. As a result, he remained at the top of the ITF for 14 years, not stepping down until 1991.

In 1979 Chatrier was elected president of the Men's International Professional Tennis Council, the body responsible for organising the Grand Prix and dealing with problems within the professional game. Thus, for six years he was the most important person in international tennis and was able to orient the ITF's policy towards developing tennis around the world. He did this by organising (or reorganising) men's and women's international tennis and providing assistance to national federations. He began his term as president by setting himself two main objectives-regulating the commercialisation of tennis and putting an end to political interference in tennis.

\section{Chatrier's First Challenge: Combat the Commercialisation of International Tennis}

Although money had been part of tennis since tournaments began at the end of the nineteenth century, the proliferation of non-official competitions and exhibition matches in the 1960s and 1970s, not to mention the payment of agent's fees and appearance fees, led to chaos. Hence, Chatrier's first commitment as ITF president was to stop entrepreneurs running their own tennis tournaments outside the ITF's control and to counter the influence of players' agents. His battle against

${ }^{46}$ La Nouvelle république du centre ouest, 8 July 1977. the professional tennis circuits turned out to be far easier than his struggle against the agents.

The ITF announced the first major change in January 1978. Henceforth, at the end of each year a jury would follow a set of welldefined criteria to designate official men's and women's world champions. In this way "everyone will know who is the real and unique champion". 47 "The success of tennis has led to endless discussions and so many classification systems that the public no longer know what to think". ${ }^{48}$ As well as results in Grand Prix, WCT and Masters tournaments, the designation as world number one would also take into account results achieved in Davis Cup matches. The ITF thereby "encouraged" every player, whether independent or under contract, to make themselves available for their national team. Chris Evert and Björn Borg were the first official world champions.

Despite the millions of dollars pumped into it and the ever-increasing prize money, Lamar Hunt's WCT circuit never seriously challenged the Grand Prix's dominance. This was largely because the players, caught in a tug-of-war between promoters and federations, gradually realised they could earn as much money while remaining independent. By 1977 the WCT was running out of steam. The following year, Lamar Hunt finally accepted the ITF's proposals and entered the official ranks; his tournaments would now be part of the Grand Prix. It may have been during these negotiations that Chatrier, in his huge office below the central court at Roland Garros, firmly explained to Hunt his "elephant theory": "The 160 nations within the International Federation are like elephants. If they are steered correctly, they have enormous strength, they are irresistible. Whatever you do, there will always be one in front of you. And another, and another, etc." ${ }^{49}$ The "Texas Ogre" threw in his hand. However, in a last-ditch effort, Hunt again withdrew

"Bellamy, R.; "ITF to pick world champions", in The Times, 17 January 1998.

${ }^{18}$ Frêne, J.; "Seule la F.I.T. décernera le titre mondial", in La Nouvelle république, 17 January 1978

19Delessalle, J.-C.; Navarro, G.; Rebière, G.; Chami, L.; Profession Président, Les Editions du sport, 1992, p. 138. 
the WCT from ITF control in 1982 and launched a parallel circuit. Four years later, Chatrier reflected on his former adversary:

Who still talks of Lamar Hunt as a force? He is reduced to half-a-dozen tournaments. He is no longer a threat to the system. My battle is to ensure tennis does not fall into the hands of private entrepreneurs. We brought Hunt into the system, whereas, if you remember, his goal was to take over tennis. We swallowed him up. And you think he didn't realise it? ?0 $^{50}$

Effectively, Hunt was aware of the situation and, in 1989, he pulled the plug on the WCT. In the case of the WTT and its intercity tournament, the situation eventually resolved itself, as the competition was never a great success and rarely managed to attract "important" players.

Tennis's ever-growing popularity had brought huge sums of money into the game, shared between players, businesses, tournaments and sponsors. Because professional players were always on the road and did not have the time to look after their own affairs, they hired managers or agents to help them negotiate contracts (advertising, television, etc.) and run the business side of their lives. Some companies, such as Proserv (Professional Services) and IMG McCormack, specialised in this type of management.

Agents began having so much control over their players' careers that their decisions could affect a tournament's survival. In contrast, Chatrier firmly believed that money from tennis should be injected back into the game and was therefore against the intrusion of these private organisations. Nevertheless, experience tempered his views: "I am convinced that professional sport should be run by non-profit bodies. That being said, I try to live with my times, to understand players' appetites. I don't blame them or their agents". ${ }^{51}$

Faced with the ubiquity of these agents, Chatrier decided that the best way to control them was to ensure they had a vested interest in

${ }^{50}$ Bouin, P.; Carducci, J.; "Notre procès est exemplaire", in L'Equipe, 21 January 1986, p. 9.

${ }^{51}$ Couvercelle, J., Jean; Delamarre, G.; "Entretien avec Philippe Chatrier", in Tennis Magazine, n'86, May 1983, p. 61. maintaining the tennis system. Hence the FFT hired Proserv's Donald Dell ("with whom he was on friendly terms", source: interview with a professional tennis player) to deal with the commercial side of television contracts, and IMG's Mark McCormarck to manage the "French Open" brand.

By rejecting the agents' business but supporting the agents, Chatrier claimed he was keeping them under control: "They are such an integral part of the system that they can't, I don't think, destroy it". ${ }^{52}$

The arrival of agents in the tennis world also generated a practice that was long denied but widely used, appearance fees, a system that puts greater value on a player's media profile and ability to attract crowds than on his or her ability to win matches. Although appearance fees were kept secret for many years, invoices entitled "Tournament appearance" have been issued since at least 1984. "President Chatrier, who is naturally against this system, has admitted on several occasions that he is powerless to stamp it out". ${ }^{53}$ For a long time, Chatrier hesitated between legalising appearance fees and taking more consequential action. In 1986 and 1987 he locked horns with the largest firms of agents (notably IMG and Proserv) by banning them from the public relations village at Roland Garros over conflicts of interest, their power as the players' representatives and their influence over the organisation and marketing of tournaments.

Another conflict over the status of players emerged at the end of the 1970s. The ATP wanted ever-greater independence, as is shown by the creation of the Nations Cup. The outlook for the Grand Prix darkened further in the 1980s, and by 1988 the ATP and the ITF were openly at war (the "Tennis War"). Even though Chatrier preferred to talk about "growing pains after 20 years of Open Tennis", ${ }^{54}$ Ray Moore, president of both the ATP and the professional council spoke of numerous deep changes giving players "greater influence over how the game 
is organised". ${ }^{55}$ These revolutions included the idea of creating a new circuit, the ATP Tour (managed by the players in conjunction with tournament organisers) and a new, computerised world ranking system. In addition, an ATP council was to be formed in order to manage the professional circuit, although the four Grand Slam tournaments would remain independent. This would reduce the ITF's role to overseeing the Davis and Federation Cups.

Powerless in the face of the players' revolt, which he undoubtedly underestimated, Chatrier could only look on as the ATP Tour was born, in 1990. "I can only wish good luck to the new circuit organised by the players themselves", ${ }^{56}$ responded the ITF's president, as he saw his powers reduced. The world's best players may have united around the ATP's executive director, Hamilton Jordan, ${ }^{57}$ but Chatrier was not giving up. Swallowing his disappointment, he began thinking of a new project.

The result, announced at the end of 1989, on the eve of the first ATP Tour, was the Grand Slam Cup, "the most richly endowed tournament in history" ${ }^{58}$ The $\$ 6$-million prize fund split the players' coalition. In fact, the players were already unhappy with the ATP's proposals, which had done nothing to reduce the number of tournaments on the calendar. The Grand Slam Cup would be a year-end competition between the best players from the Grand Slam tournaments and the Davis Cup, that is, the events still under ITF control. Paradoxically, this new cup took Chatrier into the ranks of the so-called "pirate" tournament organisers, as the tournament was not recognised by the ATP. He may have said "the cup is not a war machine against the ATP; we simply want to mark our territory", 59 but, according to one former professional player, the event "was clearly an act of vengeance against the ATP".

\footnotetext{
55a "Ray Moor: 'Les joueurs défendent leur droit"', in Le Figaro, 5-6 November 1988. ${ }^{56}$ Giroud, A.; "Bonne chance", in La Tribune de Genève, 20 December 1988, p. 35. ${ }^{57}$ Hamilton Jordan, the man of the second tennis revolution was, in turn, Jimmy Carter's campaign manager, a teacher and a writer, before becoming the ATP's executive director. ${ }^{58} \mathrm{~L}$. R.; "L'argent de la fédé sème le trouble chez les joueurs", in Libération, 6 November 1989 p. 39.

${ }^{59}$ Richard, J.-A.; "La déclaration de paix de Philippe Chatrier", in Le Figaro, 7 November 1989.
}

Chatrier defended this controversial move, saying "We created this Cup to encourage people to take part in the Grand Slam tournaments. We were frightened when we saw how the players treated the Davis Cup. We have offered them a huge carrot at the end of the year". ${ }^{60}$ Pete Sampras was the first player to grab the carrot, feeling that his win over Brad Gilbert in the final was "richly rewarded".

"Alibi" or "salve for the conscience", this tournament also allowed a large development fund to be created in order "to help 'tennis-poor' countries grow". ${ }^{61}$ But, the press invariably criticised this escalation and it was many years before Chatrier admitted that he had agreed to create the Grand Slam Cup "dragging my feet and only on condition that $\$ 2$ million would be taken from it for the development fund". ${ }^{62}$

The Grand Slam Cup disappeared from the calendar in 1999, having failed to attract anything more than pecuniary interest from the players. As one former professional player said, "it was one of Chatrier's main failures and a commercial fiasco".

But Chatrier's long-running battles against tennis's financiers and the players' desire for independence were not his only concerns. He had also set himself other goals.

\section{A Second Challenge: Reduce the Intrusion of Politics into Sport and Protect the Grand Slams}

Chatrier's second great objective was to reduce political interference in sport, mostly with respect to the Davis Cup. However, even if the Davis Cup was, as Chatrier believed, "one of the International Tennis Federation's brightest jewels" and a "fundamental symbol of stability in an ever-changing game", 63 it went through a deep crisis during the 1970 s and 1980s. Some observers went as far as suggesting that the only

${ }^{60}$ Bouin, P.; "Chatrier: 'Le dollar... l'arme de la dissuasion", in L'Equipe, 22 December 1990. ${ }^{61}$ Delessalle, J.-C.; Navarro, G.; Rebière, G.; Chami, L.; Profession President, Les Editions du sport, 1992, p. 144

${ }^{62}$ Ibid.

${ }^{63}$ Trengove, A.; The story of the Davis Cup, Stanley Paul, 1985, p. xi. 
way to preserve the event's prestige and protect its past glory would be to draw a line under it. Instead, given his love for the Davis Cup and, most importantly, seeing that it was the only event still under ITF control, Chatrier decided to change its aging format.

Immediately after his election as ITF president, he excluded South Africa and Rhodesia, evoking the need to avoid mixing tennis and politics. Hence, South Africa was banned from all team events organised by the ITF until the country had a single, unified and non-racial federation. ${ }^{64}$ With the respect to the competition's unusual format, in March 1980 Chatrier announced that the Davis Cup "is an old lady being jostled by the untrammelled growth of tennis around the world. Therefore, she needs to change and rejuvenate". Several possible formats were examined, for example, setting up a finals phase, as in the football world cup, or having the semi-finals and finals in the same place. Nostalgically, Chatrier would have liked to revive the challenge round, which had been abolished in 1972 (the winner qualified automatically for the next year's final, which was held in that team's country): "Finally, I believe we have lost a lot with the challenge round, ${ }^{65}$ as image, as an event that fired the imagination. I am told: it's fairer now. It's not obvious what we have gained, but I know what we have lost. The challenge round was something magical. The conquest, having to go and fight for the cup: was that unfair? If so, so what? Sport is cruel. And the winning team had the same advantage the following year". ${ }^{66}$ Another advantage of the challenge round format was that it increased the media bubble around the final, unlike the reform that was finally adopted, in which all the teams start again in the first round, with groups chosen according to a seeding system.

Once the Davis Cup had been saved and put on a firm footing, Chatrier turned to another endangered tradition: the Grand Slam tournaments. After restoring Roland Garros as one of the world's great

${ }^{64}$ White minority rule in Rhodesia, now called Zimbabwe, ended in 1980.

${ }^{65}$ Challenge-round: a system by which the holder of the Davis Cup played only the last match, at home (the Challenge-round), against the winner of a compecition between all the challengers. This system was abandoned in 1972.

${ }^{66}$ Couvercelle, J.; "Entretien avec Philippe Chatrier", in Tennis Magazine, $\mathrm{n}^{\circ} 36$, March 1979, p. 48. tournaments, he moved onto the southern hemisphere. In 1983, when a journalist asked him about the health of the "four great tournaments, the Grand Slam tournaments", he replied, cuttingly:

There are three, Roland Garros, Wimbledon and Flushing Meadow, which everyone knows are great successes. The public can see they have all the values: tradition, authenticity, stars. I can never stress enough how exemplary they are. They are also great guardians of the credibility of modern, elite-level tennis. I am looking forward to the coming renaissance of the Australian Open. ${ }^{67}$

Thus, in the name of the ITF and in support of Brian Tobin, the Australian federation's president, Chatrier set about revitalising the fourth Grand Slam tournament. With increased prize money, comprehensive media coverage and essential support from the ITF and its president, the Australian Open took on new life in 1987. January was fixed as the date for the tournament, in order to ensure a stable position within the international calendar, and the facilities built for the 1956 Olympic Games in Melbourne were converted into a vast tennis stadium. Paradoxically, the solution for saving the Grand Slam tradition involved sacrificing the old Kooyong stadium, the traditional symbol of Australian tennis.

Although Chatrier believed firmly in tennis's traditions, having travelled round the world some 35 times, he saw the need to develop tennis in 'tennis-poor countries'. According to one former professional player, this strategy was also about ensuring his re-election because "he owed his election to the 'small countries', against the Anglo-Saxons, who controlled the tennis business". In this case, the strategy he adopted was to take on another challenge, re-admitting tennis to the Olympic Games.

\section{Putting Tennis Back on the Olympic Programme}

Tennis firmly embraced economic globalisation during the 1970s, but it was not yet a universal sport. It had, for example, been absent from the Olympic Games since 1928, due to the supposed professionalism of

67Du Peloux, G.; Lacour, J.-P.; "Renaissance du grand chelem", in Le Figaro, 13 January 1983. 
tennis players and the discord between the IOC and ITF ${ }^{68}$ As Chatrier realised, making tennis an Olympic sport would bring more money to tennis federations through government subsidies and the redistribution of Olympic revenues to help develop tennis in countries with little tennis infrastructure. "It was a question of conscience and of responsibilities. I had to put my aside personal feelings (...). As soon as I became president of the international federation, I saw that out of 104 nations, 70 had to listen to their government, for good reason, as their subsidies came from the government". ${ }^{69}$ He also knew that Olympic status would give the ITF more power in its battles against the people who wanted to commercialise tennis. Presenting himself as a "huge fan of Olympism", Chatrier gave himself over entirely to re-establishing tennis on the Olympic programme. On achieving his objective at Seoul in 1988, he proudly declared: "I immediately realised that that had to be my top priority". 70

However, the road had been long. The first step was taken in March 1976, when the IOC, presided by Lord Killanin, officially recognised the ITF. On 20 March 1976, Chatrier was able to announce to the ITFs board of directors: "tennis has once again been added to the list of Olympic sports, but this does not presuppose its return to the Olympic Games..." 71 Nevertheless, ITF members attending IOC meetings were able to raise the issue of tennis's return as an Olympic event. The subject was debated at the 1978 IOC congress in Athens, but no major advances were made until the 1981 IOC Session in Baden-Baden. Here, the IOC's new president, Juan Antonio Samaranch, helped tennis, which had become a symbol of the sporting revolution and the end of amateurism, become a demonstration sport at Los Angeles 1984. According to Chatrier:

${ }^{68}$ For more details: La Raquette et les anneaux. Histoire du tennis aux Jeux Olympiques, Tenniseum Roland-Garros, September 2000.

${ }^{69}$ Couvercelle, J.; "Entretien avec Philippe Chatrier", in Tennis Magazine, ${ }^{\circ} 36$, March 1979, p. 48 .

${ }^{70}$ Maria, P.; "L'année Chatrier", in L'Equipe, May 1988.

${ }^{71}$ Article 14 of the minutes of the Executive Committee meeting on Saturday, 20 March 1976.
Antonio Samaranch played a very important preparatory role. I obtained the decision in April, at Seoul, at a meeting of all the national Olympic committees, thanks to the magic phrase "as an experiment". Presenting the problem in this way allowed those opposed to the project to accept it without feeling they were compromising their principles. Funnily enough, it was a Soviet executive who made me re-use the magic words "as an experiment", which had been very effective in 1968 in gaining acceptance for open tennis. ${ }^{72}$

Following the success of the Olympic tournament in California, the IOC congress in Istanbul confirmed tennis's return for the Seoul Olympics in 1988, the ITF's 75 anniversary year. This was an immense satisfaction for Chatrier, for whom: "Our sport has regained its spurs and widened its audience even further. Everyone respects an Olympic medal". ${ }^{73}$ At the IOC, Samaranch hailed the victory of the man René Lacoste called "Mr Tennis", "a president who is both pragmatic and a visionary". Samaranch attributed Chatrier's success to his "admirable tenacity" and "diplomatic talents". ${ }^{44}$ With hindsight, it could be argued that the Olympic label did not really help develop tennis around the world, especially in Africa, Oceania and Asia (apart from China). Furthermore, some players feel that tennis does not really belong in the Olympics, that it would be better to make way for other sports, and that Olympic tennis receives scant media coverage.

In September 1990, Count Jean de Beaumont gave up his seat at the IOC. Chatrier was chosen to take his place and asked to preside the important commission responsible for the Olympic programme. A few months earlier, in June 1990, after seven terms and fourteen years as ITF president, Chatrier had announced that he would not stand for re-election in July. He had decided to focus his energies on the IOC.

"If Philippe Chatrier had not fought his main battles, the tennis world would surely function differently today, and some Grand Slams might have gone under. He was successful on the international stage

"22 "Le Point avec le président", in Tennis de France, n407, March 1987, p. 230.

${ }^{73}$ Chatrier, P.; "Ultime satisfaction", in Tennis Info, n²33, July-August 1991, p. 1.

"Haedens, F.; "Mort d'un géant", in L'Equipe, 24 June 2000. 
because he spoke English and he was an anglophile who could talk on equal terms with the Anglo-Saxons, as it was they, mostly the Americans and Australians, who controlled tennis" (source: interview with a former professional tennis player).

The "Chatrier system" left a legacy that went far beyond the FFT, ITF and Tennis Europe (the European Tennis Federation, through which Chatrier helped structure European tennis). In fact, for many observers, analysts and members of French and international sport bodies (sports ministry, CNOSF, IOC, etc.) Chatrier's work, first at the FFT and then internationally, produced an effective "business model" for developing any sport, not just tennis.

\section{Chatrier's Legacy}

Chatrier's legacy is first and foremost philosophical and ethical. Although he carried out most of his work within a non-Olympic organisation, his philosophical and ethical principles were at the heart of late-twentieth century Olympism. His legacy was also managerial, as he was a "non-profit entrepreneur" who injected a modern and revolutionary vision of management into sports federations in France and abroad, and, more generally, into the entire sports and Olympic movement.

\section{Philosophical and Ethical Legacy}

The 1970s and 1980s were a pivotal period in the evolution of sport, which underwent several structural and cultural changes, most notably in terms of the relationships between sport and money and between sport and politics, against a background of increasing globalisation. Moreover, elite sport was becoming increasing professional, especially following the IOC's decision, taken in 1981, to remove the reference to amateurism for participants in the Olympic Games.

Chatrier remained inflexible in his attitude toward the issues of sport and money and sport and politics, despite the criticism he incurred during his time as president of the ITF, especially with respect to his role in creating the "Grand Slam Tour". His doctrine was clear: "Our sport must remain outside politics and be run by federations, not by governments". ${ }^{75}$ For Chatrier, only sport federations, within a strong sports and Olympic movement, were capable of guaranteeing the vital link between elite (national team), professional and grassroots sport. In a world where sport is dominated by money, Chatrier fought tirelessly to promote this ideal:

"Agents and sponsors are necessary but you have to make them understand that, 1, the dividends of sport must be reinvested in its development and, 2, the independence of sport federations must be maintained." "I am prepared to fight for my convictions. Because sport is not immune from being dominated by money. I don't want mediocrities to take over sport. That would make them too smug. You could say I am fighting them with their own weapon, money. But what's wrong with that if it helps me achieve my goals. ${ }^{" 76}$

Hence, on both national and international levels, he built and championed a model based on solidarity and the reinvestment of money in sport, so sport remains under the control of the federations, not of private entrepreneurs. In addition, helped by Juan Antonio Samaranch, Chatrier fought strongly to obtain tennis's readmission into the Olympic programme, which he saw as a way of globalising the development of tennis, especially in former eastern bloc countries. "Promoting sport requires money and $80 \%$ of governments provide money only for the Olympics. Tennis wins out because, in addition to benefitting from the prestige of the Games, we benefit from the solidarity fund, which allows us to help, among other things, our development sector". ${ }^{77}$

All Chatrier's actions as federation president included a message and a vision of how sport should be developed. This development could be achieved only by professionalising the sports movement and structuring it so it was able to preserve its independence. Hence, Chatrier's legacy was also managerial, as the system he introduced was based on

75ource: interview in L’Express 13-19 December 1976.

76 Source: interview in Le Figaro 13 January 1983.

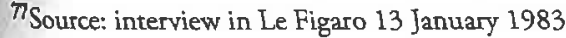


a management doctrine and management principles that were highly effective and much more modern than those used by other French sports federations in the 1970 s and 1980s.

\section{Managerial Legacy}

When Philippe Chatrier stepped down as president, the FFT was France's largest sports federation (Table 7.3).

By the end of his presidency, Chatrier had placed the FFT on a particularly healthy and stable financial footing (Table 7.4). His successor was able to continue this financial policy thanks to the enduring success of Roland Garros.

Table 7.3 Size of the FFT in 1992 (when Chatrier stepped down as president) compared with the French Football Federation and French Basketball Federation

\begin{tabular}{|c|c|c|c|}
\hline & Tennis & $\begin{array}{l}\text { Football (including the } \\
\text { professional league) }\end{array}$ & Basketball \\
\hline No. of registered players & $1,330,000$ & $1,953,000$ & 386,000 \\
\hline $\begin{array}{l}\text { No. of permanent head- } \\
\text { quarters staff }\end{array}$ & 143 & 109 & 18 \\
\hline Budget (million francs) & 345 & 250 & 41 \\
\hline Total payroll (million francs) & 51 & 32 & 5 \\
\hline $\begin{array}{l}\text { Payroll as percentage of } \\
\text { budget }(\%)\end{array}$ & 14.7 & 12.8 & 12.1 \\
\hline
\end{tabular}

Table 7.4 Fluctuations in the FFT's financial situation between 1991 and 1997

\begin{tabular}{llllllll}
\hline Year & 1991 & 1992 & 1993 & 1994 & 1995 & 1996 & 1997 \\
\hline $\begin{array}{l}\text { Net profit } \\
\text { (in K francs) }\end{array}$ & 48,000 & 67,630 & 67,709 & 47,618 & 39,853 & 32,203 & 50,659 \\
$\begin{array}{l}\text { after tax } \\
\text { Net worth }\end{array}$ & 185,471 & 252,379 & 319,300 & 366,267 & 405,400 & 432,983 & 483,642 \\
$\quad$ (in K \\
$\quad$ francs) \\
$\begin{array}{l}\text { Net } \\
\text { balance } \\
\text { (in K } \\
\text { francs) }\end{array}$ & 334,000 & 379,091 & 458,594 & 560,100 & 651,800 & 652,830 & 715,729 \\
$\begin{array}{l}\text { Net worth/ } \\
\text { net balance } \\
\text { (\%) }\end{array}$ & 55.5 & 66.5 & 70 & 65.4 & 62.2 & 66.3 & 67.5 \\
\hline
\end{tabular}

One of Chatrier's aims was to ensure the FFT's capacities were constantly adapted to the sporting, organisational and commercial challenges it had to face. In 1976, he stated: "My concern is to handover to my successors a federation fit for the 1980s. That is, one whose day-to-day operations are supervised by permanent managers. In this way, elected officials will not have to give over all their time to the federation. They will just have to define policy and steer the federation's actions. I am building a tool. There will be 800,000 registered players in five years and a million soon after. We need a federation equal to this challenge". ${ }^{78}$

The management methods Chatrier introduced in his federation focused on five key elements in ensuring high performance:

- An effective system of governance (i.e., one that facilitates the emergence and implementation of strategic projects and the monitoring of the results obtained);

- An efficient federal network (i.e., the relations and cooperation between the federation's head office and its leagues, local committees and clubs);

- An optimal position within its economic sector;

- A team of professional managers to implement policies under the supervision of elected administrators;

- A strong organisational culture that unites elected officials and salaried managers behind a common objective.

Governance includes decision-making and control methods, as well as the roles played by governing bodies (executive committee, steering committee), elected officials and paid managers. Chatrier wanted this governance to be based on unity.

On the one hand, he established the tradition of giving each regional league president a seat on the federation's steering committee. As well as ensuring the system was representative, this predominance of league presidents within the system's governance had a number of advantages, including homogeneity, coherent management and the easy circulation

${ }^{78}$ Interview with P. Chatrier in Tennis magazine, May 1976. 
of information. On the other hand, it also had potential drawbacks, such as cumbersome management and league presidents putting their leagues' interests ahead of the federation's interests. ${ }^{79}$ However, the biggest risk for the FFT was to have too narrow a range of expertise among the members of the steering committee. In fact, the committee's 45 members include 12 "college members" and 33 independent candidates, 31 of whom are league presidents.

On the other hand, relationships between elected officials and paid staff were clearly defined: elected officials determine policies; salaried managers implement these policies. Chatrier filled the role of the (unpaid) president who coordinated and protected the system. ${ }^{80} \mathrm{His}$ charisma and authority, and the sporting, financial and organisational results he achieved, firmly justified maintaining this system.

The quality of the federal network, that is, the quality of the collaboration between the federation, regional leagues, departemental committees and clubs in implementing a development policy, is essential in determining a sport federation's capacity for growth (Bayle, 1999). In terms of developing the clubs, Chatrier favoured action on the regional level, via help to professionalise the leagues, rather than on the départemental level. By the end of Chatrier's presidency, the FFT had become increasingly professional, both at the federation's head office and at the leagues, with professional senior staff in three areas: sport, administration and development. Having such a "triumvirate" of directors remains unique among France's sports federations.

The FFT's position within its economic sector (sale of tennis goods, linked to subscription fees and tennis lessons, and to events, etc.) has improved continuously. The economic and financial model Chatrier developed for the federation was based on the success of Roland Garros, but it also includes events the federation owns and, to a much lesser

79" At the end of the 1980, the governors of the FFT realised that the self-election system had been very positive for building the federation on a united foundation but once built and stable it could turn into a disadvantage by favouring immobility" (source: interview with a governor). In fact, Philippe Chatrier's successor was criticised for the clientilist way in which he used this governance system. ${ }^{80 "}$ A few politicians, even those close to Chatrier, were shocked by the salaries paid to the main sporting and even administrative executives. But Chatrier stuck to his guns" (source: interview), extent, leisure tennis. Consequently, the FFT has successfully captured the majority of the financial resources available to French tennis, much of which it redistributes and re-injects into the federal system. Significantly, during Chatrier's presidency France became the second largest host of ATP and WTA tennis tournaments, which were often set up in order to generate profits for the leagues and for the tennis ecosystem in general.

The penultimate success factor was delegating management to professionals (with specific skills, a passion for tennis and who supported Philippe Chatrier) under the supervision of elected officials. The FFT had around 10 paid employees when Chatrier arrived but more than 150 salaried staff when he stepped down (approximately $1 / 3$ at RolandGarros, $1 / 3$ at the national technical directorate and $1 / 3$ for federal tennis). "We were sensible enough to hire top-rate professionals to manage our business. We pay them well and there you are" ${ }^{81} \mathrm{He}$ also managed to put together a group of passionate and highly committed regional officials who believed in what he was trying to achieve. As a result, Chatrier was able to create a homogeneous structure for the regional leagues.

Professionalism was achieved within the regional leagues but it did not filter down to the grass-roots level, where the large number of clubs and fragmentation of resources (notably caused by the " 5000 courts" project, which was detrimental to the larger clubs) meant it was almost impossible for all clubs to have professional staff with the managerial skills that would have helped them increase their membership. The introduction of a qualitative approach (a new approach to training, support for clubs, see Bayle 1999) was mostly the work of Chatrier's uccessor.

Finally, the organisational culture: created during the Chatrier era brought together elected officials and salaried staff without creating conflicts between the two groups. The result was a professional but closeknit atmosphere that generated a strong feeling of commitment to the 1999).

Interview with P. Chatrier in Tennis magazine, May 1983. 
Although they were developed during the 1970s, these five key performance factors still seem highly modern in the management of French and international sports federations. The policies and management methods implemented by the FFT under Philippe Chatrier may have evolved, but they remain the foundations of the federation's success.

\section{Conclusion}

Philippe Chatrier is widely esteemed as one of the greatest administrators in French and world sport. There are a number of reasons for this. First, thanks to his unceasing commitment to tennis at every level, he had a perfect grasp of the strategic issues involved in finding a balance between:

- The Grand Slam and Davis Cup tournaments (controlled by the ITF), the interests of players and the interests of the entrepreneurs who set up men's and women's professional circuits;

- Elite-level, competition and grassroots tennis;

- Unpaid administrators and salaried managers;

- The federation's public service mission and its commercial development.

In addition, his actions were founded on a clear vision of the links, both intrinsic and financial, between elite, professional and amateur sport. This vision resulted in him adopting a pioneering position with respect to tennis's relations with money and politics, the two major issues of the time. Finally, although his actions are rooted in sport's traditions, they still appear revolutionary and very modern because they were applied in a context that was both very favourable (era of open competitions, massive growth in grassroots sport, increased commercialisation of sport thanks to money from television and sponsors, etc.) and very challenging, due to commercial operators contesting the monopoly exercised by the traditional sports and Olympic movement.
Acknowledgements I would like to thank Isabelle Aimone for providing access to documents on Philippe Chatrier held by the Musée du Tennis.

I would also like to thank my colleagues, Carine Erard and Lionel Crognier, for their precious advice concerning the text. A special thank you must go to FFT staff and Philippe Chatrier's friends and family for agreeing to share their information with me.

\section{Bibliography}

Bayle, E. 1999. Management et performance des organisations à but non lucratif: le cas des federations sportives françaises. Management Sciences Doctoral Thesis, University of Limoges $(750$ pages and 500 pages of Appendices).

Irlinger, P., C. Louveau, and M. Métoudi. 1988. Les pratiques sportives des Français. Paris: INSEP.

Reneaud, M., and F. Rollan. 1995. Tennis: pratiques et sociétés. Talence: Maison des Sciences de l'Homme d'Aquitaine.

Terret, T. (ed.). 2003. Education physique, sport et loisirs 1970-2000. Paris: AFRAPS.

Waser, A.-M. 1995. Sociologie du tennis. Genèse d'une crise. L'Harmattan Logiques sociales. 